\title{
Parques do Brasil: a concepção de uma série de documentários de história natural e a pro- moção da conservação da biodiversidade e das unidades de conservação brasileiras'
}

\author{
Carlos Sanches ${ }^{2}$ \\ Luciana Alvarenga ${ }^{3}$
}

\section{Resumo}

Revisitando o processo de criação da série de TV Parques do Brasil parte da equipe que concebeu o projeto analisa os objetivos, as justificativas e as escolhas que definiram o formato e a estética da produção e, ao mesmo tempo, a situam dentro do contexto histórico dos filmes de história natural, da conservação da biodiversidade e do patrimônio natural, e, do estabelecimento de unidades de conservação.

\section{Palavras-chave}

História Natural; Biodiversidade; Cinema; Unidades de Conservação; Patrimônio Natural

\begin{abstract}
Revisiting the process of creating the TV series Parks of Brazil, part of the team that conceived the project analyzes the objectives, justifications and choices that defined the format and aesthetics of production and, at the same time, situate it within the historical context of the natural history films, the conservation of biodiversity and natural heritage, and the establishment of protected areas.
\end{abstract}

\section{Keywords}

Natural History; Biodiversity; Cinema,; Protected Area; Natural Heritage

\section{Introdução}

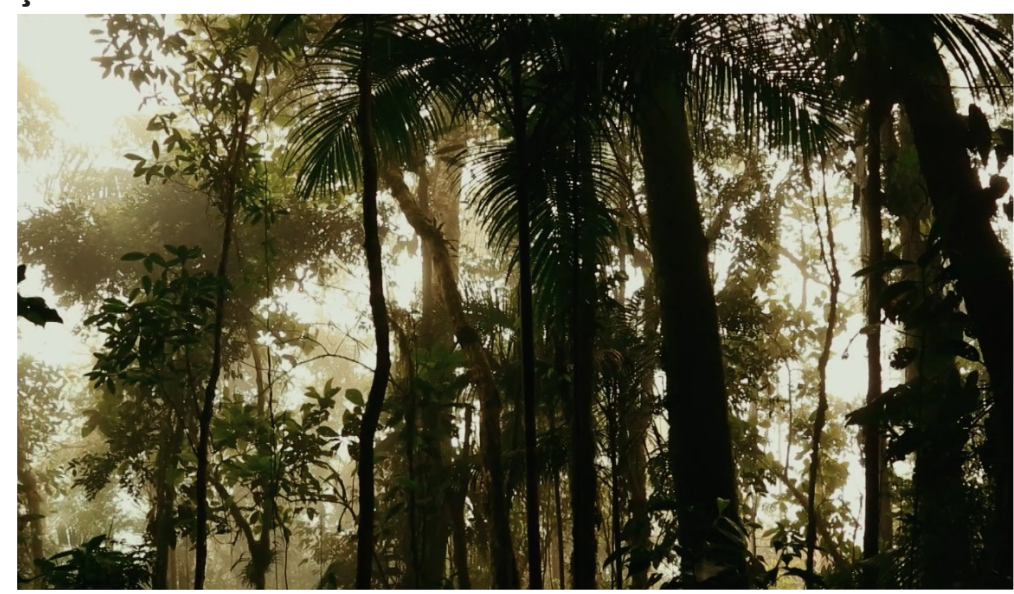

Imagem lente 24-105mm. Floresta Atlântica do Parque Nacional de Itatiaia, RJ.Vídeo promo da série Parques do Brasil.

\footnotetext{
I O projeto conta com recursos do CNPq e é fruto da parceria entre a Casa de Oswaldo Cruz/Fiocruz, a TV Brasil/EBC e o Instituto Chico Mendes de Conservação da Biodiversidade-ICMBio.

2 Diretoria de Produção e Conteúdo - DIPRO/TV Brasil/EBC. carlos.sanches@ebc.com.br. Bacharel em Comunicação Social (UFF) e cineasta.

3 Casa de Oswaldo Cruz-Fiocruz. luciana.alvarenga@fiocruz.br. Doutora em Artes Visuais/História e Teoria da Arte (UFRJ), mestre em Ciência Ambiental (UFF) e bióloga (UFES).
} 
Parques do Brasil:a concepção de uma série de documentários de história natural e a promoção da conservação da biodiversidade e das unidades de conservação brasileiras

Os filmes de história natural surgem nos primórdios do cinema, a partir de um longo processo histórico de representação da natureza, fruto das contradições que permeiam a relação dos seres humanos com outras espécies, num planeta em eterna transformação. Definido como gênero de caráter documental (Davies, 1998: 159), nasce integrado ao desenvolvimento de tecnologias e de inovações no campo da captação e da exibição de imagens em movimento, liga-se a processos educativos, científicos e de entretenimento, e, projeta-se dentro da indústria cultural. Em suas narrativas encontramos reflexos dos movimentos de caráter ambiental deflagrados no final do século $X I X$ e no século $X X$.

Esses filmes são categorizados através de várias denominações, muitas delas repletas de preconceitos e simplificações, como filmes sobre a vida selvagem, documentários de natureza ou de animais, blue-chips, entre outras. Aqui optaremos pelo filme de história natural (Davies, 1998: 12) por considerá-lo mais adequado aos objetivos e às formas de produção deste subgênero audiovisual, que apresenta uma práxis singular dentro do universo da produção de cinema e de televisão, relacionando-se de maneira umbilical com um amplo conjunto de disciplinas científicas que estudam os ambientes naturais e seus organismos.

As origens do filme de história natural remontam ao surgimento das ilustrações científicas, ao Romantismo, aos relatos de viajantes-naturalistas dos séculos XVIII e XIX, ao romance de aventura, à invenção da fotografia, às experiências científicas sobre o movimento de animais desenvolvidos por Muybridge e Marey (Janson, 2007), aos travelogues e às exibições das lanternas mágicas (Da-Rin, 2004: 40-4I; Burns, 1998:7). Desenvolve-se a partir da linguagem construída pelo documentário clássico em várias partes do mundo e do interesse das pessoas em conhecer a diversidade de ambientes e de espécies que existe no planeta.

Em meados do século $X X$, em paralelo ao surgimento de organizações civis como a International Union of Conservation of Nature - IUCN, surge a Unidade de História Natural da BBC de Londres. Pouco tempo depois, acompanhando a evolução das câmeras e demais equipamentos, os filmes de história natural se tornam sucessos de público, ganham prêmios e se consolidam no universo da produção audiovisual. Em 1993, a unidade de produção inglesa recebe o título de centro de excelência para o cinema (Davies, I 998: I I). Apesar disso, a crítica cinematográfica nunca considerou os filmes desse subgênero relevantes dentro da história do audiovisual (Ramos, 2008: 4 I; Davies, 1998: 28-29). Em tempos mais recentes, algumas produções foram acusadas de reforçar a dicotomia entre o homem e a natureza (Williams, 1980:77), e de promover uma visão romântica, mítica ou estilizada de áreas naturais e de animais silvestres (Bousé, 2000: 121 ).

O Brasil é o país com maior biodiversidade do mundo (MMA, 20I7), mas tal magnitude não se reflete numa filmografia nacional. No país são produzidos programas jornalísticos sobre temas ambientais, como o Expedições (TV BRASIL, 2018a) e o Repórter Eco (TV Cultura, 20I8). E também documentários como: Lixo Extraordinário (Jardim e Walker, 2009), O Sal da Terra (Salgado e Wenders, 20I4) e A Lei da Água (D’Elia, 20I5). Os filmes de história natural realizados no Brasil são de produções estrangeiras em sua grande maioria. Tal fato se dá talvez por alguns motivos: dificuldades técnicas de produção, falta de equipe especializada, a necessidade de elevados recursos, e, também por escolhas conceituais e de mercado.

Em 2018, no Dia Mundial do Meio Ambiente, a TV Brasil exibiu o documentário Parque Nacional das Emas (TV BRASIL, 20I8b), um episódio da série 
Parques do Brasil, uma coprodução inédita entre a Casa de Oswaldo Cruz/FIOCRUZ, o Instituto Chico Mendes de Conservação da Biodiversidade - ICMBio e a TV Brasil/EBC (Alvarenga e Sanches, 2018: 224). Com exibições semanais, muitas reprises e praticamente sem divulgação, a série obteve uma audiência média significativa dentro do padrão da TV Brasil (Kantar IBOPE media, 2018). Este artigo pretende contextualizar as escolhas conceituais e estéticas realizadas durante o processo de criação desta série, relacionando-as com a evolução deste subgênero na história da produção audiovisual e com a conservação da biodiversidade.

\section{A série e seus objetivos}

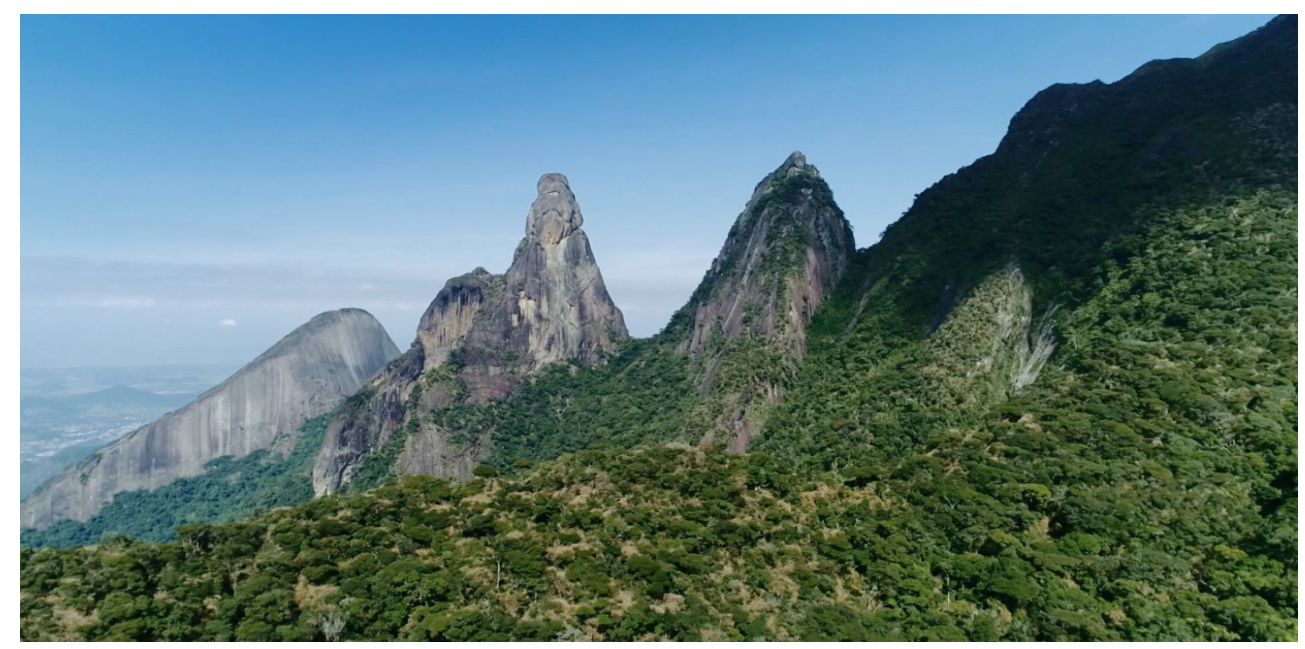

Imagem aérea/drone. Parque Nacional da Serra dos Órgãos, RJ.Vídeo promo da série Parques do Brasil.

Parques do Brasil é uma série de TV e web que tem como objetivo apresentar as unidades de conservação de proteção integral brasileiras, enfatizando a diversidade de ambientes e de espécies da fauna e da flora existentes nesses locais, destacando os sítios declarados pela UNESCO como Patrimônios Naturais Mundiais (Unesco, 20I8). Além disso, pretende revelar a importância desses lugares para a manutenção de serviços ecossistêmicos que são essenciais para a vida das pessoas (Alvarenga e Sanches, 2018: 224).

A série é fruto de um Convênio estabelecido entre a COC/FIOCRUZ e a EBC, e, de um Acordo firmado entre a COC/FIOCRUZ e o ICMBio. Os objetivos dessas duas cooperações técnicas se alinham na produção de conteúdos audiovisuais sobre a biodiversidade e as unidades de conservação federais brasileiras (Alvarenga e Sanches, 2018: 224).

Apresentando seis episódios com durações que variam entre 22 e $31 \mathrm{mi}-$ nutos, a primeira temporada desta série foi gravada entre maio de 2017 e junho de 2018 , mas utilizou também imagens captadas desde 2014 . O formato do projeto foi desenvolvido praticamente no mesmo período. A temporada começou a ser exibida regularmente no dia 8 de agosto, às quartas-feiras, no horário das 2 Ih45. 
Parques do Brasil:a concepção de uma série de documentários de história natural e a promoção da conservação da biodiversidade e das unidades de conservação brasileiras

\section{A concepção do projeto}

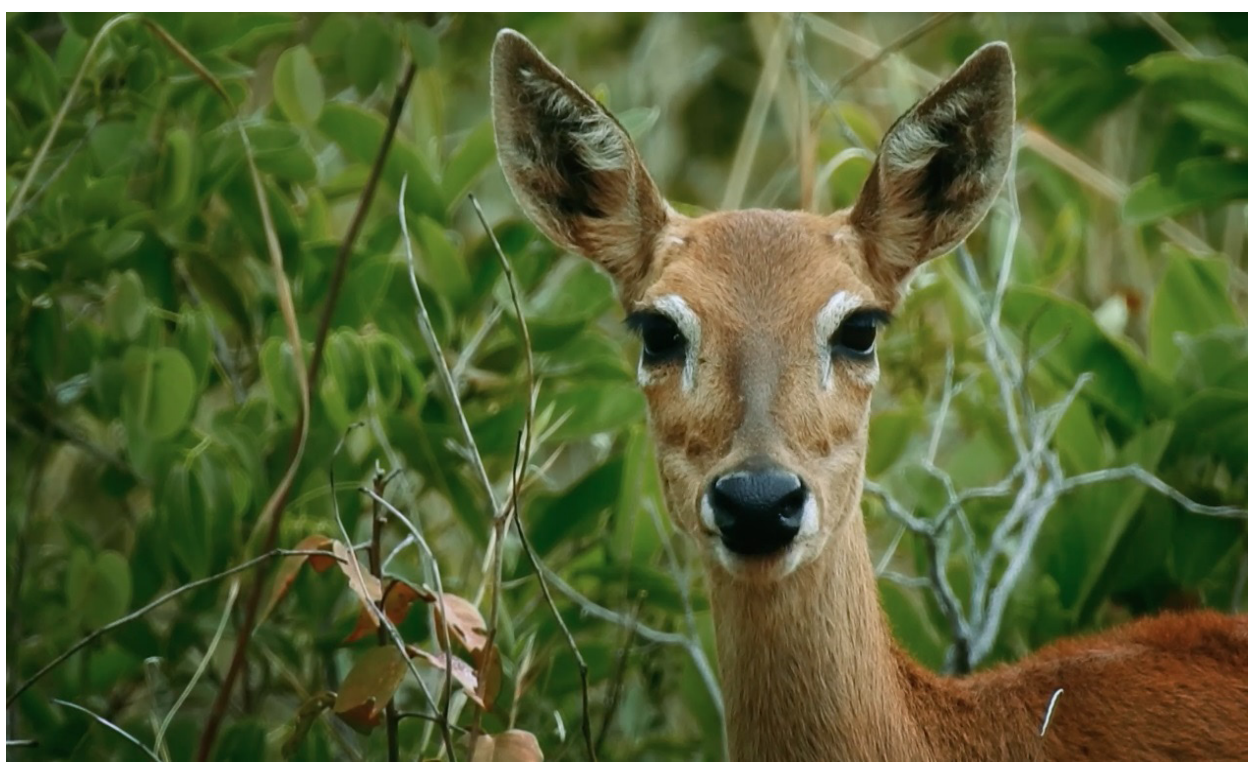

Imagem lente 100-400 com duplicador 2x.Veado-campeiro (Ozotoceros bezoarticus).Episódio Parque Nacional das Emas,GO/MS.

A concepção de uma série de TV envolve questões variadas, de escolhas artísticas a procedimentos administrativos internos. Aqui vamos nos ater ao processo de formatação do projeto: as referências utilizadas e o porquê de determinadas escolhas ou definições. Este processo se deu num período longo, que envolveu pesquisas, reuniões, testes de equipamentos e muito trabalho em campo.Algumas escolhas são pessoais ou dizem respeito ao grupo que concebeu a obra, outras surgem de limitações impostas pelas condições orçamentárias e pela estrutura de produção. Mas é importante ressaltar os motivos que nortearam a criação desta série, fundamentais para entender as escolhas conceituais.

A ideia do projeto surgiu de algumas constatações. Em 2012, o Ministério do Meio Ambiente apresentou os resultados da quinta edição de uma pesquisa que avalia a percepção da população brasileira sobre o meio ambiente (as outras foram realizadas em 1992, 1997, 2001 e 2006). A pesquisa destacou que: praticamente $100 \%$ diz ser fundamental cuidar do meio ambiente e $65 \%$ apontaram a sua importância para a sobrevivência humana.A temática aparece como a sexta maior preocupação do brasileiro (nas pesquisas anteriores não figurava entre as (10). Na mesma pesquisa, $56 \%$ dizem saber o que é uma área protegida e $62 \%$ a consideram importante para proteger todas as espécies vivas de um determinado local.A pesquisa aponta ainda um crescimento visível no interesse da população, destacando que $65 \%$ acham que é preciso controlar a produção para não afetar o ambiente e $77 \%$ não consideram a preocupação com o tema exagerada (MMA, 20I2). Ainda a respeito de constatações temos no mesmo período o crescimento da visitação nos parques nacionais (Beraldo e Simões, 2018) e o surgimento no Brasil de programas e canais voltados à divulgação da biodiversidade, como o Nat Geo Wild, a BBC Earth e o Animal Planet.

Por outro lado, também nesta mesma época, percebemos no Congresso Nacional brasileiro o surgimento de propostas apoiadas em sua maioria pelo agronegócio e pelo setor minerador visando: enfraquecer o Sistema Nacional 
de Unidades de Conservação - SNUC e impedir a criação de mais áreas protegidas (PEC 2I5/2000), desafetar parte ou extinguir áreas já estabelecidas (PL 375 I/20I5), legalizar a caça profissional e a esportiva (PL 6268/20 I6), e, fragilizar os mecanismos legais de proteção ao meio ambiente (Lei I2.65 I/20I 2 - Novo Código Florestal-; PEC 65/2012; PLS 654/2015; PLS 620/2015; PEC 76/20II; PL 1610/1996). Nos trabalhos de campo realizados desde 2014 constatamos que todas as unidades de conservação brasileiras sofrem algum tipo de ameaça, mas que as unidades de proteção integral, ou seja, as que não permitem o uso direto dos seus recursos são as mais ameaçadas.

Mesmo com o crescimento da visitação e o aumento do interesse da população, nos trabalhos de campo realizados e em visitas a escolas e outras instituições, observamos que o brasileiro ainda conhece pouco a biodiversidade e as unidades de conservação do país. Por isso, decidimos tornar a diversidade de espécies e as UCs de proteção integral os objetos centrais da série. Na busca por um nome de fácil compreensão e rápido entendimento, optamos por evidenciar o tipo de unidade mais popular e conhecido: o parque nacional. $\mathrm{Na}$ proposta de tentar abarcar as mais diferentes regiões surgiu então o nome Parques do Brasil.

Mas qual seria o formato? Optaríamos por um documentário expositivo clássico com comentários em OFF, imagens ilustrativas e uma trilha musical? Ou seria algo nos moldes do cinema direto norte-americano, com planos-sequência, o som em sincronismo com a imagem, a equipe invisível e sem comentários em OFF? Talvez um modelo que revelasse a equipe interagindo com pesquisadores? Ou uma proposta metalinguística?

Desde o início a proposta era atingir um público amplo, de jovens a idosos, de todos os gêneros, de centros urbanos e de áreas rurais, com escolaridades variadas e diferentes níveis socioeconômicos.A ideia era produzir algo acessível, mas que não fosse apenas um desfilar de belezas naturais e de animais desconhecidos ou ferozes. Não seria uma aula, nem um filme hermético ou experimental. Não queríamos aparecer na frente das câmeras, até porque a equipe técnica em campo é tão reduzida que isso acabaria atrapalhando a produção. Pretendíamos fugir das entrevistas e de qualquer formato mais jornalístico, metalinguagem ultrapassava as nossas pretensões e cinema direto não cabia numa proposta que pretendia colocar animais, plantas e ambientes como personagens.

Nos documentários ambientais citados na introdução deste artigo a biodiversidade é parte de um conjunto abstrato que se convencionou chamar de meio ambiente. Nestas obras, a maioria dos fenômenos ecológicos e quase a totalidade das espécies não possuem um significado relevante dentro do enredo. Geralmente o foco central é a relação destrutiva da civilização ocidental com esse meio ambiente total ou, no caso do filme $O$ Sal da Terra, a redescoberta da natureza pelo artista.

Assim, resolvemos buscar um caminho diferente deste para contar as histórias desses personagens e optamos por utilizar o modelo expositivo como um ponto de partida. Para desenvolver o projeto a partir desse modelo, analisamos séries da BBC como Planet Earth (Fothergill, 2006), Life (Holmes, 2009) e Nature's Great Events (Bassett, 2009), além de filmes como Le Peuple Migrateur (Perrin, 200I). Esses documentários apresentam imagens espetaculares da natureza e oferecem entendimentos sobre diversos fenômenos que acontecem nos ecossistemas. Os impactos da civilização global são expostos de diferentes maneiras em alguns deles, mas nenhum delimita as unidades de conservação onde os eventos narrados acontecem. São obras vistas por milhões de pessoas em todo o mundo, com orçamentos caros e uso de tecnologias de ponta, mas que 
Parques do Brasil:a concepção de uma série de documentários de história natural e a promoção da conservação da biodiversidade e das unidades de conservação brasileiras

trazem em suas narrativas reflexos dos primórdios do cinema. São objeto de admiração e também de críticas, e, carregam a marca contraditória da relação do homem com o ambiente.

\section{Os filmes de história natural}

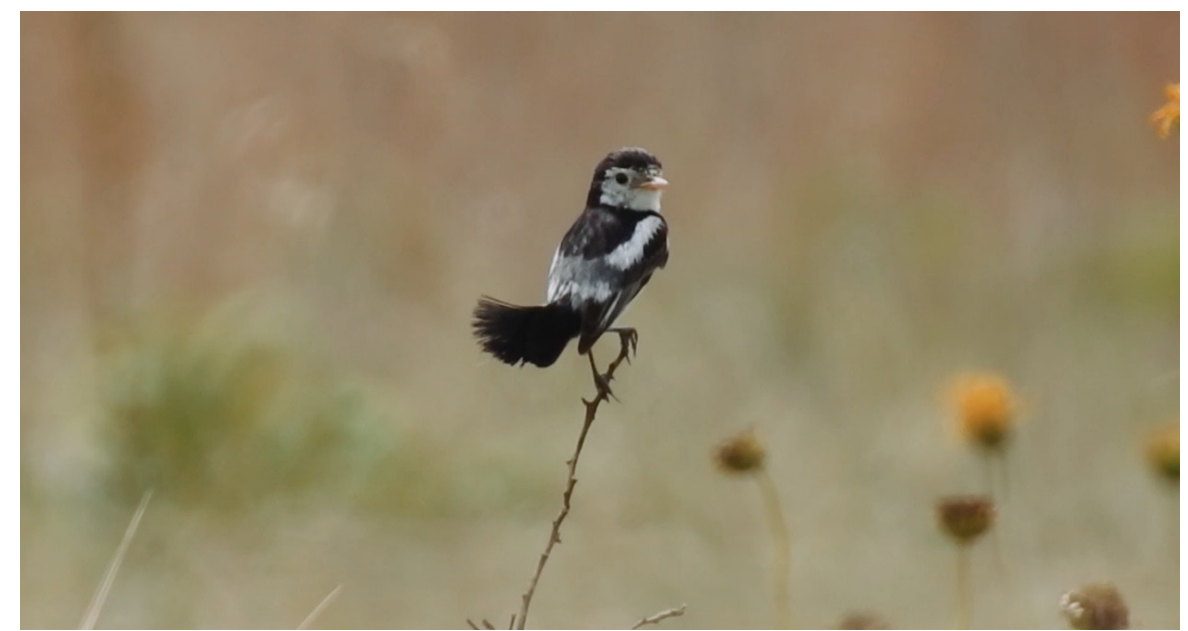

Imagem lente 100-400 com duplicador 2x. Galito (Alectrurus tricolor). Episódio Parque Nacional das Emas, GO/MS.

O documentário não deve ser considerado uma reprodução da realidade, mas uma representação do mundo histórico e social que todos compartilhamos (Da-Rin, 2004: 133-136). Independente das nossas vontades, nessas obras estão lá as marcas deste universo e da nossa cultura, forjados numa construção em que os conceitos de "história" e "natureza" estão implicados um no outro (Adorno, 1984: III-I24).

A história natural remete a uma visão aristotélica de ao mesmo tempo investigar o mundo natural em suas formas observáveis e de narrar uma história através de uma cadeia de eventos numa relação de causa-efeito que ocorre no espaço e no tempo, servindo de base tanto para o romance literário, quanto para a construção do cinema clássico narrativo, seja ele ficcional ou não-ficcional (Singh, 2005: 4). As origens do filme de história natural estão diretamente relacionadas aos movimentos conceituais e artísticos, científicos-tecnológicos e econômicos que marcam o final do século XVIII e todo o século XIX, tendo o surgimento da fotografia com uma de suas expressões mais relevantes para o nosso interesse:

Os primórdios da fotografia refletem a visão e o temperamento românticos: na verdade, o século XIX tinha uma curiosidade generalizada e a forte convicção de que tudo podia ser descoberto. Se este fascínio se manifesta por vezes em um interesse sério pela ciência - veja-se a viagem de Darwin no Beagle, de I831 a 1836 normalmente tomou a forma de uma procura inquieta de novos lugares e experiências.A fotografia teve um extraordinário impacto na imaginação desta época, tornando o resto do mundo acessível, ou simplesmente revelando-o sob uma forma diferente (Janson, 2007 : 882-883). 
Nesta busca incessante por revelar diferentes mundos e realidades, a fotografia serviu tanto para produzir obras realistas quanto experimentais. Meio século depois da sua invenção, possibilitou uma pequena revolução na observação científica da natureza. Em 1877, o fotógrafo inglês Eadweard Muybridge (I8301904) apresentou uma série de fotografias que mostrava "um cavalo trotando que mudou para todo o sempre a representação de um cavalo em movimento" (Janson, 2007: 936). Forjando a imagem em movimento, produziu mais de 100 mil fotografias com imagens de animais em diferentes ambientes, além de experiências sobre o movimento do corpo humano. No mesmo período, o médico e professor francês Etienne Marey (1830-1906) divulgava seu próprio trabalho em Le Mouvement ( I894), onde registrou com sua câmera cronofotográfica múltiplas imagens de um pássaro em voo. Para ele só a câmera lenta ou acelerada tinha interesse do ponto de vista da síntese científica (Janson, 2007: 936-937).

Nessas tentativas bem sucedidas de revelar e estudar o movimento de animais e do próprio ser humano nascia a possibilidade concreta do cinema e, ao mesmo tempo, do filme de história natural. Embora possamos voltar ainda mais no tempo e resgatar a história da evolução da ciência óptica e da física que teve na lanterna mágica a precursora dos projetores de cinema e da exibição de imagens como um espetáculo. Este invento foi criado pelo padre jesuíta e cientista Anthanasius Kircher em 1640, devidamente registrada no livro de sua autoria Ars Magna Lucis et Umbrae em 1645 (Burns, 1998: 7). Sem este artefato talvez não houvesse se constituído o espaço de exibição que a fotografia e o cinema depois ocupariam. As lanternas mágicas possibilitaram também a ilustração de palestras realizadas por viajantes-exploradores e professores de ciências naturais (Da-Rin, 2004: 40-4I).

Em 1895, os irmãos Lumière lançam o cinematógrafo e a síntese do fazer documental:"escolher o melhor enquadramento para capturar um instante da realidade e filmá-lo sem nenhuma preocupação nem controlar nem centrar a ação" (Burch, 1987:36). Quase ao mesmo tempo aparecem os travelogues ou filmes de viagem, centrados na figura do viajante-explorador-realizador, numa abordagem puramente descritiva da natureza, sem construção narrativa e sem costura, apresentando cronologicamente pequenos trechos de expedições em lugares longínquos. $O$ termo foi cunhado por Burton Holmes que se considerava um performer ao realizar palestras sobre viagens ilustradas através da projeção de imagens fixas ou em movimento (Da-Rin, 2004: 40-4I).

Em 1903, surge um dos primeiros filmes de história natural: The Cheese Mites. Este curta-metragem revela a vida microscópica que floresce numa fatia de pão com queijo, filmada através de um microscópio por Francis Martin Duncan (Screenonline, 2018). Em 1910, o cineasta britânico F. Percy Smith (I8801945) lança The Birth of a Flower que mostra uma flor se abrindo, inaugurando a utilização da técnica hoje muito difundida do time lapse, chamada por ele de time magnification (Wild Filmhistory, 20I8), que a Unidade de História Natural da BBC tornou lendária no episódio Plants da série Life (Holmes, 2009). Smith produzirá vários outros filmes que hoje fazem parte da história do cinema de história natural como The Plants of the Pantry (1927), Magic Myxies (I93 I) e The World in a Wine-Glass (193I).

Além de Smith, em torno da British Instructional Films, surgem realizadores como Charles Head, Captain H. A. Gilbert, Oliver G. Pike, Walter Higham e Mary Field. The Cuckoo's Secret (1922) apresenta uma singularidade que depois se tornará uma característica básica do filme de história natural. Um dos cineastas pioneiros neste gênero de filme, Oliver G. Pike se juntou ao ornitólogo 
Parques do Brasil: a concepção de uma série de documentários de história natural e a promoção da conservação da biodiversidade e das unidades de conservação brasileiras

Edgar Chance para produzir um filme de 17 minutos inédito sobre os hábitos peculiares de nidificação do cuco (Cuculus canorus). Esta espécie tem o costume de colocar os seus ovos nos ninhos de outras aves insetívoras. Ao nascer, o fiIhote elimina os outros recém-nascidos e passa a receber cuidados exclusivos de sua mãe adotiva. Pike colocou câmeras em torno de possíveis ninhos onde isso pudesse acontecer, conseguiu imagens antológicas e a primeira prova documentada sobre esse fenômeno (Wild Filmhistory, 2018; Screenonline, 20 I8).

A constante busca por técnicas para captar os fenômenos da natureza, bem como a parceria entre artistas-técnicos e cientistas, serão características identificadoras deste tipo de produção audiovisual. Os melhores filmes de história natural serão aqueles que conseguirem equilibrar esses dois universos de conhecimento.

Por utilizar em sua maioria imagens captadas em ambientes exteriores e reais, o filme de história natural logo virou subgênero do documentário e, assim herdou seus conflitos, principalmente aqueles relacionados à verdade e à representação. Segundo Metz ( 1980:45), a linha divisória entre o cinema ficcional e o não-ficcional será tênue.

O surgimento do termo documentário surgiu ao mesmo tempo em que a escrita documental cinematográfica expositiva estava sendo forjada. $O$ produtor e cineasta escocês John Grierson cria o termo numa crítica ao filme Moana (1926) de Robert Flaherty que ele diz ter "valor como documentário" (Da-Rin, 2004: 20). Flaherty revolucionou o cinema ao lançar Nanook of the North ( 1922) narrando o cotidiano de uma família de esquimós na Baía de Hudson, no Canadá. Diferente dos filmes de viagem, a história era centrada nesta família e apresentava uma montagem que manipulava o espaço-tempo. Numa assumida interpretação da realidade, dialogava com o filme de ficção, utilizando personagens reais em encenações que retratavam tradições do passado. Para Flaherty o cinema "não é uma função da antropologia ou da arqueologia, mas um ato de imaginação". Grierson pouco tempo depois vai delinear a estética e a tradição do documentário clássico narrativo como um "tratamento criativo da realidade", onde se deve "enfatizar a força que o cinema pode extrair do ambiente e imaginar uma história capaz de lhe conferir significado humano" através de uma relação com o objeto fílmico onde "você fotografa a vida natural, mas também, pela justaposição do detalhe, a interpreta". Mas Grierson reforça o aspecto educativo do documentário, criticando a teatralização e o romantismo do cinema de Flaherty. Para ele era preciso filmar a "cena viva e a história viva", buscar uma "representação naturalista", mas ao mesmo tempo, possibilitar a realização do artista "ao interpretar o material, o documentarista pode, de acordo com sua personalidade, introduzir os elementos de imagem poética, de tensão dramática e de movimento sinfônico". Dentro do aspecto educativo, quase civilizatório, ele encara o documentário como uma ferramenta de transformação da sociedade (Da-Rin, 2004: 45-85).

O cinema soviético irá extrapolar esses conceitos desenvolvendo diferentes caminhos para lidar com o objeto, a verdade-realidade e a narrativa, de um cinema que pretende "a verdade expressa por todo um leque de possibilidades cinematográficas" do kinopravda de Vertov à montagem intelectual de Eisenstein e Dovzhenko e ao construtivismo de Pudovkin (Da-Rin, 2004: 109-132; Dancyger, 2007: 15-32).

Em parte influenciado esteticamente pelo cinema soviético, o norte-americano Pare Lorentz lança em 1936 um dos primeiros documentários ambien- 
tais. The Plow that Broke the Plains mostra os impactos da agricultura descontrolada nas Grandes Planícies dos Estados Unidos. Em 1938, ele produz The River, que destaca a importância do Rio Mississippi e revela como as práticas agrícolas e madeireiras fizeram com que o solo fosse arrastado rio abaixo para o Golfo do México, levando a inundações catastróficas e empobrecendo agricultores. Os dois filmes ganharam o prêmio de "melhor documentário" no Festival Internacional de Cinema de Veneza (Dancyger, 2007: 60-62).

Nos Estados Unidos, a conservação da natureza surge como ciência nos séculos XIX e XX através de nomes como Henry David Thoreau, John Muir, John Burroughs e Aldo Leopold (Singh, 2005: 5). No mesmo período, escritores como Herman Melville e Jack London lançam obras literárias onde a natureza terá um papel de destaque. Melville lança Moby Dick em I85I. London escreveu obras como The Call of the Wild (1903), The Sea Wolf (1904) e The White Fang (1906). Em 1872 é criado o primeiro parque nacional norte-americano: Yellowstone. A criação dos parques nacionais nos Estados Unidos fortaleceu uma concepção motivada pelas novas descobertas da biologia e por uma filosofia inspirada no romantismo (Franco e Drumond, 2009: 46-48). Em 1892, Muir funda a primeira organização conservacionista: a Sierra Club (Singh, 2005:5). Em 1916 nasce o National Parks Service.

No início do século $X X$, nos Estados Unidos e no Canadá, surgem escritores populares que vão se especializar em narrativas envolvendo animais como Charles D. Roberts, William J. Long, Ernest Thompson Seton e James Oliver Curwood. Na época Long foi acusado de realizar falsa ciência ao narrar histórias fantasiosas como se fossem observações científicas verdadeiras. Um ponto em comum na obra desses autores é a tendência em dar aos animais características e emoções humanas. Curwood realizará a ponte entre esta literatura popular e o cinema. Pelo menos dezoito filmes foram produzidos a partir das obras deste autor. (Singh, 2005: 7).

Em 1948, após dirigir o premiado longa-metragem de animação Fantasia (1940), o diretor, produtor e roteirista James Algar inicia a série True-Life Adventures da Disney com o filme Seal Island. Em 1953, ele lança The Living Desert, que faz estrondoso sucesso e ganha o Oscar de melhor documentário. Ao todo foram produzidos 14 longas-metragens onde hoje fica patente a influência de narrativas que procuram dar ao mundo animal características sociais humanas, com histórias que giram em torno de dramas familiares nitidamente norte-americanos, buscando evidenciar o sensacionalismo em detrimento do conhecimento científico. Em menor grau essa antropomorfização do mundo selvagem continuará sendo uma das marcas da Disney Nature em filmes como Chimpanzee (Fothergill e Linfield, 20I2), por exemplo (Singh, 2005; Bousé, 2000; Mitman, 2009).

$\mathrm{Na}$ década de 50, no Reino Unido, o produtor Desmond Hawkins e o naturalista Peter Scott realizam a primeira transmissão de um programa de televisão de história natural na BBC. Hawkins e o produtor Frank Gilliard criam a Natural History Unit-NHU em 1957. O naturalista David Attenborough que apresentava o programa Zoo Quest desde o final de 1954 será um dos mais importantes colaboradores desta unidade, transformando-se não muito tempo depois num de seus principais símbolos. Neste período, a principal dificuldade era a falta de profissionais capacitados e as limitações técnicas para a captação de imagens em ambientes naturais. A primeira produção colorida da BBC foi The Major (1963) que contava a história de um carvalho inglês. O primeiro filme exibido em cores foi The Private Life of the Kingfisher (1966), de Ron Eastman, es- 
Parques do Brasil: a concepção de uma série de documentários de história natural e a promoção da conservação da biodiversidade e das unidades de conservação brasileiras

crito e produzido por Jeffery Boswall. Em 1979, surge a primeira grande série de história natural: Life on Earth, esboçada e escrita por Attenborough e filmada em 39 países (BBC, 20I4). A série obtem um sucesso estrondoso e abre caminho para as grandes séries da NHU-BBC como The Blue Planet (Byatt e Fothergill, 200I) e Planet Earth (Fothergill, 2006). Depois de sessenta anos de atividade, a NHU é hoje provavelmente o maior centro de desenvolvimento de tecnologias e de produção de filmes de história natural (Art \& Humanities Research Council, 2017).

Os filmes da Disney e as séries da BBC ganharam um apelido jocoso: blue-chips. O termo é originário dos cassinos e faz referência às fichas azuis, consideradas as mais valiosas. Também é utilizado para denominar ações de empresas bem estabelecidas, de grande porte e de comprovada lucratividade (Sandroni, 1999:57-58). Alguns filmes de história natural são criticados por supostamente apresentar um mundo natural heteronormativo ou simplesmente antropomorfizado. Uma crítica recorrente é a espetacularização da natureza (Bousé, 2000; Chris, 2006; Mills, 20I3). Produções são acusadas de negligenciar o cuidado com as informações de cunho científico, simplificando ou omitindo fenômenos ou dados, e, de reforçar uma divisão conceitual entre natureza e cultura, entre o ser humano e o mundo natural, propagando imagens de uma natureza intocada sem seres humanos. Para esses críticos os chamados blue-chips não apresentam os impactos das atividades humanas sobre as espécies e os ambientes, minimizam mensagens ambientais graves e urgentes, transmitindo através da criação de um mundo idílico de belas imagens um sentimento de que os ecossistemas não estão sob ameaça. (Mabey, 2005; MacDonald, 2006; Austin, 2007).

Tendo como meta estabelecer as diretrizes conceituais da série, analisamos várias produções consideradas blue-chips e notamos que existe em muitas dessas críticas uma generalização excessiva. Corroborando com esta observação, produtores de filmes de história natural e pesquisadores contestam algumas dessas alegações por considerar determinadas análises ortodoxas ao extremo, fomentando conceitos a partir de filmes específicos, além de subestimar as motivações e intenções de realizadores e a lógica do setor produtivo audiovisual. Além disso, negligenciam o fato de que todos os cineastas interveem de alguma maneira na natureza ao produzirem suas imagens (Palmer, 2010; Ivakhiv, 2013; Gouyon, 2016). Na prática do dia-a-dia em campo percebemos que existe também em muitas dessas críticas negativas um desconhecimento sobre as singularidades da produção de um filme desse tipo.

Segundo Louson (20I8), o contexto do entretenimento deve ser considerado essencial para a identidade do gênero e não deve ser visto como uma restrição à precisão científica. $O$ espetáculo visual possui uma função relevante ao oferecer uma experiência não só didática, mas emocional. A origem dos filmes de história natural está atrelada aos eventos de exibição das lanternas mágicas e outros espetáculos que utilizavam imagens para impactar o público e, ao mesmo tempo, transmitir informações. Os blue-chips seriam uma versão cinematográfica dos grandes museus de história natural do século XIX, que utilizam o espetáculo como forma de educação e de sensibilização:

Esta visão geral do papel do espetáculo na exibição da história natural aprimora nossa análise de filmes contemporâneos da vida selvagem. Primeiro de tudo, fundamenta a investigação do espetáculo dentro um contexto histórico e disciplinar mais amplo: a história natural sempre trabalhou para inspirar admiração e maravilhar os espectadores com ilustrações e espécimes exibidos (Louson, 2018: 30, tradução nossa). 
$\mathrm{Na}$ concepção desta série se buscou construir uma narrativa que permitisse uma experiência afetiva ligada à curiosidade e ao envolvimento, sem no entanto gerar entendimentos equivocados, como a humanização de espécies não-humanas e a criação de analogias entre sistemas sociais completamente diversos.

\section{A construção da narrativa}

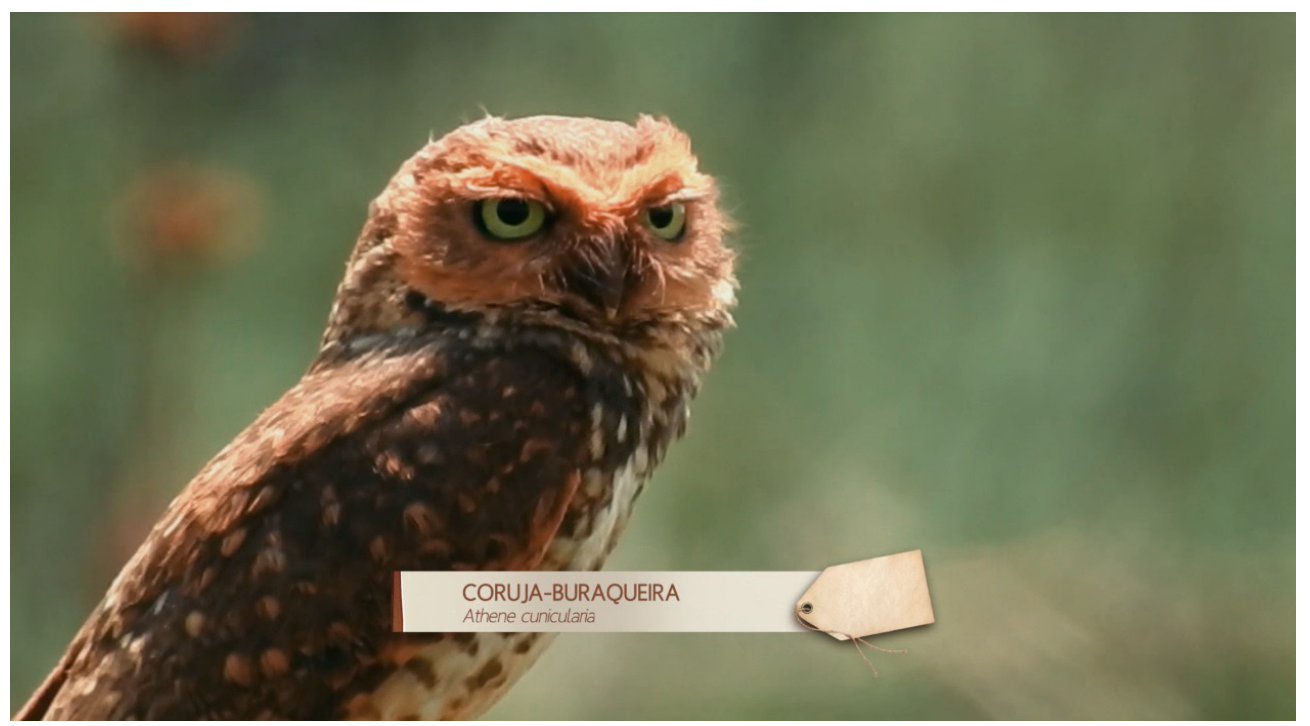

Imagem lente 100-400 com duplicador 2x. Episódio Parque Nacional das Emas, GO/MS

Para este projeto foi fundamental identificar cada espécie, legitimando-a enquanto um ser diferente de nós e de outras espécies, com necessidades diferentes das nossas, vivendo realidades diversas, nas quais muitas vezes o ser humano tem pouca influencia ou relação direta.Assim, a valorização da biodiversidade e de sua conservação é também a promoção do direito à vida de todas as espécies - a defesa do modo particular de cada espécie de viver e de se relacionar com a sua própria e com outras espécies, e, com o mundo ao seu redor.

Ao mesmo tempo, pretendemos evidenciar os processos ecossistêmicos e as interações entre espécies e ambientes, incluindo as relacionadas às atividades produtivas humanas. Diferente do que é apresentado em muitos filmes de história natural, para o objetivo do projeto é fundamental revelar os limites, o isolamento e a dimensão de cada UC, apontando transformações e diferentes impactos que problematizam a conservação.

As narrativas moldam a nossa realidade e estão presentes na história do homem desde a pré-história (Bousé, 2000: 19). Diferentes formas de narrar vão contar histórias distintas, com resultados diversos. Partindo de um modelo documental expositivo, a narrativa de Parques do Brasil é construída a partir do ponto de vista de um narrador dentro da história (Rabiger, 2007 : 123-124). Cada episódio apresenta uma expedição através de uma ou mais UCs. O narrador não aparece em quadro e fala na primeira pessoa do plural, representando um porta-voz da equipe de naturalistas que realiza o trabalho. Esse porta-voz não existe na realidade e foi criado com o objetivo de conduzir o espectador através da expedição, apresentando espécies e ambientes, relatando acontecimentos singulares, eventualmente tecendo opiniões ou impressões, propondo reflexões, instigando às vezes o espectador a olhar um fato ou imagem através de um prisma determinado, comentando sempre com alguma emoção o que é 
Parques do Brasil: a concepção de uma série de documentários de história natural e a promoção da conservação da biodiversidade e das unidades de conservação brasileiras

visto e o que não é visto.

Apesar de ser aquele que diz como determinado fato aconteceu, não se coloca como detentor do conhecimento ou de uma realidade. Narra a experiência de um grupo de pessoas que interpreta o ambiente natural através da observação e de algumas informações coletadas.

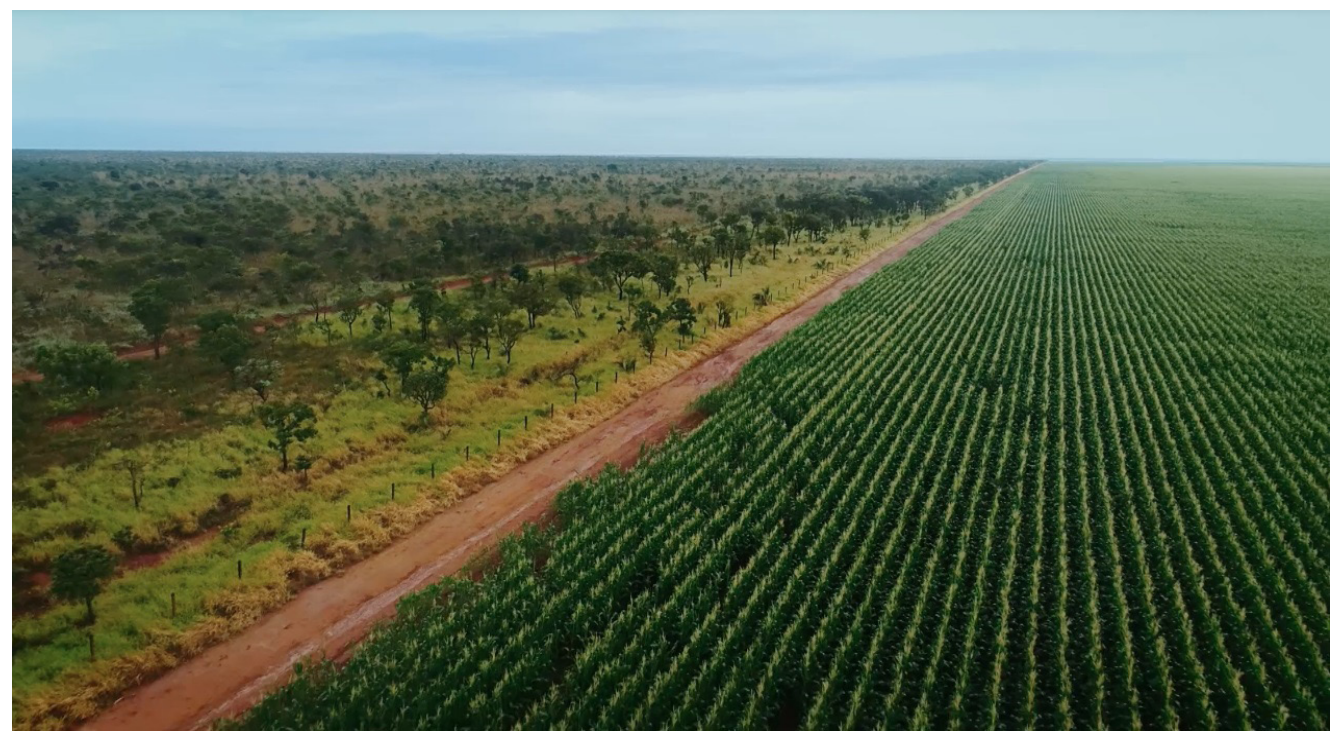

Imagem aérea/drone. Limites da unidade de conservação com plantação de milho. Episódio Parque Nacional das Emas, GO/MS.

\section{O diário de campo}

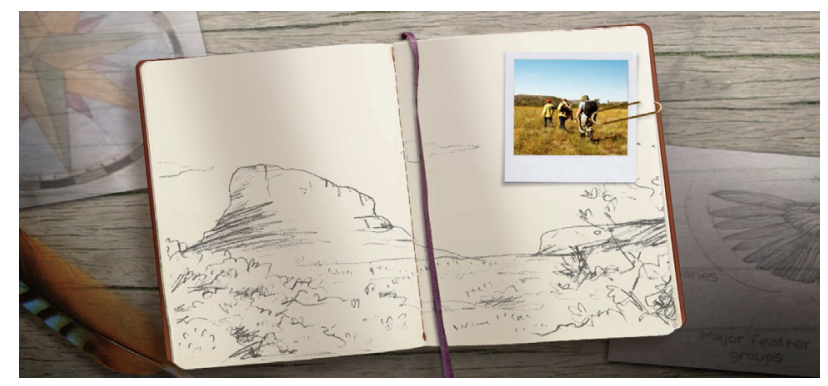

Imagem vinheta de abertura da série Parques do Brasil.

A estrutura de cada episódio se assemelha a um diário de campo. A narrativa se aproxima de um relato com histórias que aconteceram num tempo pretérito próximo. Apesar de ficar bem claro que estes fatos já ocorreram, a narração procura resgatar o frescor do acontecimento, como se o mesmo surgisse diante dos olhos do narrador e do espectador ao mesmo tempo. Este narrador não se limita à concretude da expedição e não se pretende inteiramente realista.Até porque este naturalista-narrador narra a partir de diferentes imagens, produzidas através de equipamentos e de técnicas distintas. Assim, ele pode ver do alto, de perto, de longe ou voando. Ele pode ainda falar do que viu e do que não conseguiu ver, de algo observado a algo imaginado.

Fora a introdução e a conclusão, a narrativa é linear e cronológica, revelando o dia-a-dia do trabalho de campo. Eventualmente, abre um parêntesis temporal para descrever acontecimentos que ocorreram em mais de um dia e vai além da descrição de ambientes e de espécies, pois se concentra no relato 
e no compartilhamento de uma experiência. $O$ que se vê ou se mostra não é a realidade ou uma realidade, mas uma interpretação de um relato. Esta narrativa-relato utiliza a imagem do caderno de campo como um dos seus principais componentes visuais-narrativos.

Esta imagem icônica é encontrada na vinheta de abertura e em várias artes gráficas da série. Esta nada mais é do que um caderno de campo, onde as imagens são desenhadas, fotografias são coladas e páginas são viradas através de uma animação/computação gráfica. Uma derivação simplificada dessa arte de abertura é utilizada em ilustrações no decorrer de cada documentário, revelando espécies e histórias que não puderam ser gravadas pelas câmeras. Tal identidade está presente em todo o conjunto gráfico da série e também em outros dois elementos: nos mapas que localizam as UCs e nas tarjas que lembram etiquetas onde são identificadas as espécies.

As referências visuais utilizadas na construção desses elementos remetem a diferentes formas de representação da natureza. Podemos enxergar nelas traços de pinturas de paisagem, mas a sua elaboração tem como ponto de partida a ilustração científica. Esta surge no Renascimento, período onde o desejo de redescobrir o mundo e o próprio ser humano marca as sociedades da época. No campo da ciência, as descobertas de Copérnico geram mudanças de ponto de vista na relação do homem com o mundo físico e o espiritual, e, o artista passa a ser um observador deste novo universo que se apresenta. Neste contexto, Leonardo Da Vinci (1452-I5I9) cria a moderna ilustração científica, juntando às regras da perspectiva as leis da natureza, e, define o olho humano como "o instrumento perfeito para adquirir conhecimento." Da Vinci estuda e desenha o comportamento-movimento da água num lago durante um dilúvio, retratando ondas e turbilhões. Começa a enxergar as sombras que a própria natureza projeta no ambiente natural, nas árvores e nos campos (Hauser, 2003; Janson, 2007). Segundo Attenborough (2017: 15), ele "começou a notar os corpos de animais e plantas de outra maneira. Queria entender como cresciam, se moviam e se reproduziam, então ele não apenas os desenhou em movimento, como os dissecou."

Nos séculos XVI, o médico suíço Conrad Gesner (I5I6-1565) considerado o pai da zoologia compila um catálogo chamado Historia animalium com desenhos de várias fontes, criados a partir de peles e esqueletos, além de espécimes mortos coletados. Já no século XVII, Cassiano Dal Pozzo (I 588- I657) estabeleceu o museu cartaceo ou museu de papel, com 2500 desenhos de animais e plantas, a maioria desenhados pelo pintor Vincenzo Leonardi (fl. I62 I-I646). $\mathrm{Na}$ mesma época, Alexander Marshal (c. 1620-1682) se dedicou a pintura de plantas e flores (Attenborough, 2017: 17-26).

As ilustrações de história natural representam um gênero de imagem científica que agrega tanto estudos gráficos de organismos vivos como animais e plantas, quanto paisagens-ambientes naturais. Essas ilustrações foram influenciadas pelo desenvolvimento da pintura, mas possuem estilos e convenções pictóricas singulares (Blum, 1993). Estão intimamente relacionadas à exploração mundial da natureza, à descoberta de novas espécies e à tentativa de codificar e de interpretar o mundo natural (Stafford, 1996).A ilustração científica estará no cerne do esforço de ordenar o mundo natural nas obras e trabalhos de Carolus Linnaeus (1707-1778) e de Georges-Louis Leclerc, Conde de Buffon (17071788) (Blum, 1993). Sua evolução se dará a partir do século XVII e acompanha o trabalho de desenhistas e pintores ao redor do mundo. 


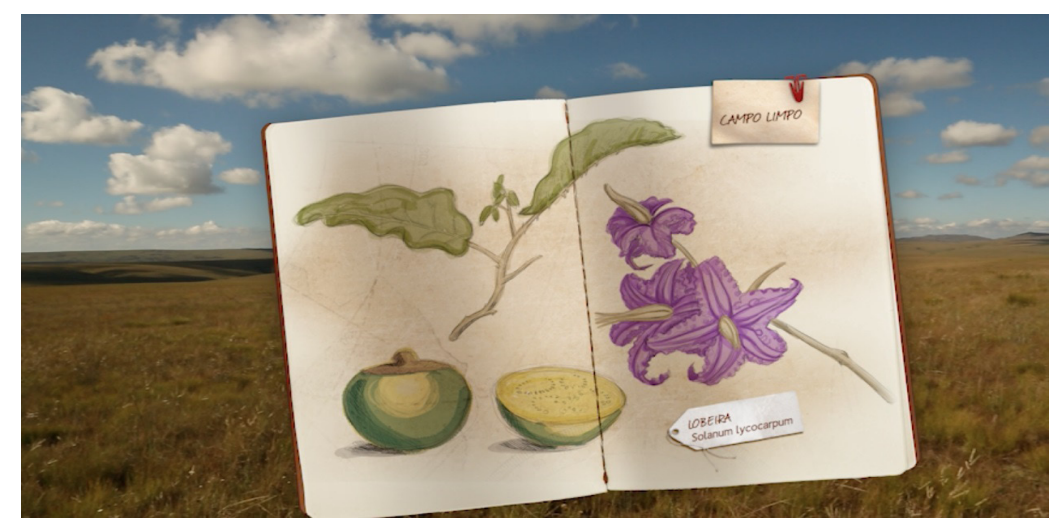

Imagem arte diário de campo. Episódio Parque Nacional da Serra da Canastra, MG.

Em 1699, Maria Sibylla Merian (I647-17I7) viajou com a filha para o Suriname, na América do Sul, registrando numa mesma pintura as diferentes fases da metamorfose de uma borboleta.Além de borboletas e outros insetos, registrou serpentes, anfíbios, aves e mamíferos (Owens, 20I7). A partir do século XVIII: o capitão James Cook ( 1728-1779) vai para a Austrália e os Mares do Sul;Alexandre von Humboldt (1769-1859) conhece a América e atravessa a Rússia; Charles Darwin (1809-1882) viaja no Beagle até as Ilhas Galápagos e passa pelo Brasil; e Alfred Russel Wallace (1823-1913) vai até a Amazônia e à Malásia (Wulf, 20I6; Rice, 1999). O desenho e a pintura se consolidam como instrumentos da ciência nas mãos de artistas como Hércules Florense (1804-1879), Thomas Ender (1793-1875), Aimé-Adrien Taunay (I803-1828) e vários outros.

Além de dialogar com essas experiências pioneiras do passado, a série incorpora elementos que foram desenvolvidos no decorrer da história do cinema e do audiovisual. É explicitamente uma série de TV, formatada como tal, apresentando capítulos e blocos, com uma vinheta de abertura e uma arte no final por onde passam os créditos. Por outro lado, engendra uma narrativa que agrega elementos e cuidados de uma produção cinematográfica.

\section{A imagem e o som}

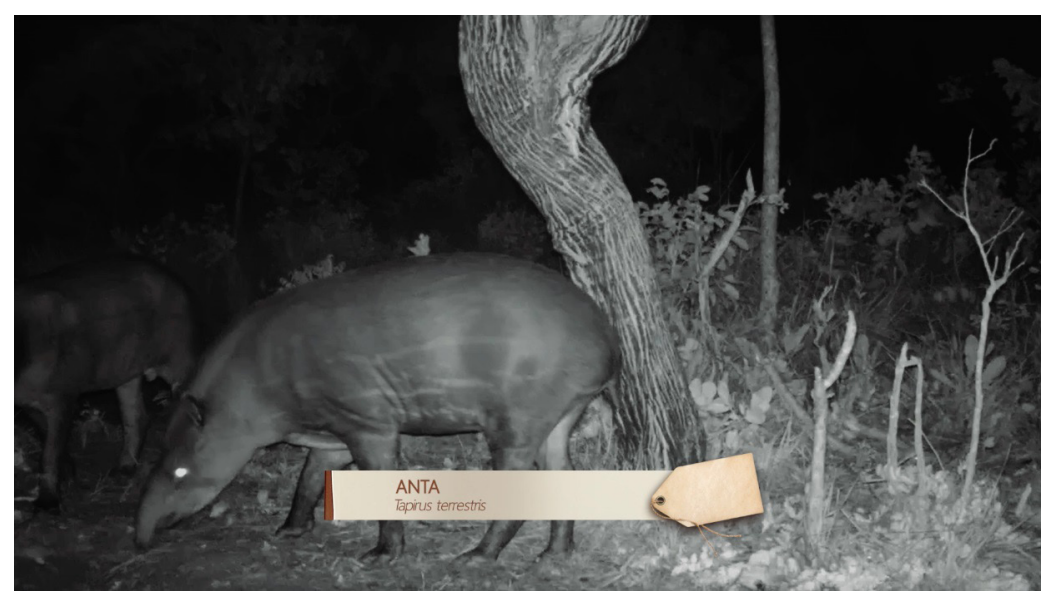

Imagem camera trap. Episódio Parque Nacional das Emas,GO/MS. 
A tradição ocidental de ver e de valorizar a visão em detrimento de outros sentidos se consolida no Renascimento. A imagem fotográfica já foi tida como prova incontestável: "um espelho de cujo testamento material ninguém poderia suspeitar". Marcado pelo fetichismo do documento, o pensamento positivista do século XIX considerava as imagens de natureza como verdades (Da-Rin, 2004: 142). Mas a capacidade de um plano ser ao mesmo tempo sobre o que a câmera mostra objetivamente e sobre a subjetividade do criador "explica o fascinante dualismo que está no coração do cinema” (Cousin, 2013:9).

As imagens dos ambientes naturais e das espécies são as bases desta série documental, buscando captar a natureza encontrada nessas unidades de conservação da maneira como ela se apresenta ao cinegrafista, ainda que a construção da narrativa seja uma interpretação da realidade captada.

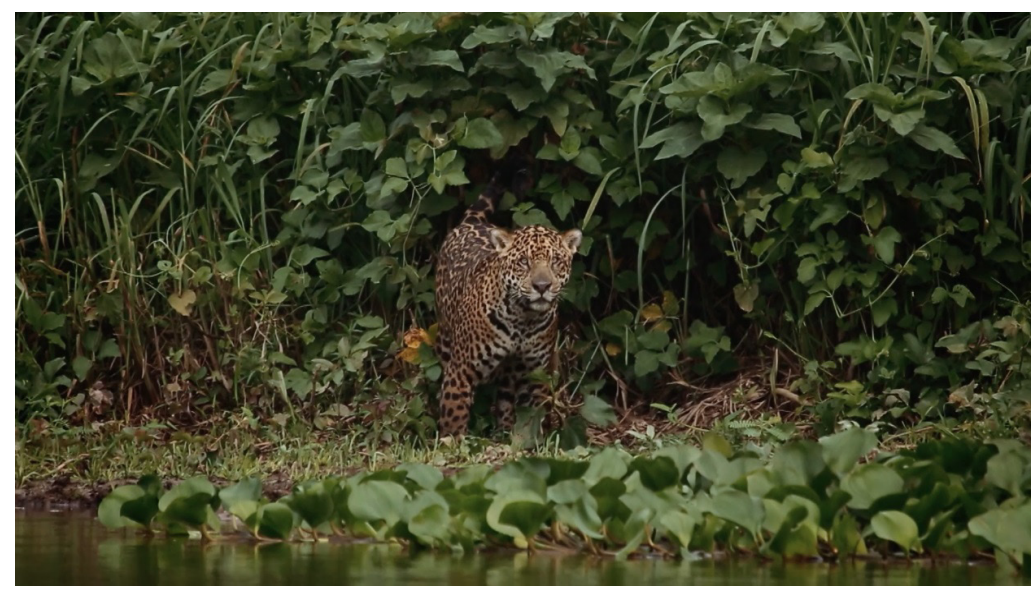

Imagem lente 100-400mm com duplicador 2x. Onça-pintada (Panthera onca). Estação Ecológica de Taiamã, MT. Vídeo promo da série Parques do Brasil.

Os personagens principais são as espécies, os cenários são os ecossistemas. $O$ enredo é a relação das espécies entre si e com o ambiente. A câmera é objetiva, eventualmente subjetiva. A narrativa intercala planos gerais fixos ou em movimento, com detalhes de plantas e de animais em ação. As imagens são produzidas através de recursos diversos como drones e lentes de diferentes tamanhos e características - teleobjetivas, normais, zooms e macros.

Outro equipamento utilizado é a armadilha fotográfica ou camera trap. Através dela conseguimos captar imagens de animais sem a presença do cinegrafista, criando um artifício repleto de contemporaneidade, de caráter efêmero e episódico. Este equipamento surgiu como instrumento científico e funciona da seguinte forma: amarrada numa árvore ou outro suporte, na altura que for mais adequada à espécie que se pretende captar, a câmera utiliza um sensor de calor que dispara quando animais de sangue quente (aves e mamíferos) se aproximam.

Os filmes de história natural evoluíram juntamente com as técnicas de captação de imagens da natureza. As sequências em câmera lenta, as imagens de time lapse e as infravermelhas, os close-ups extremos da macrofotografia, são encarados pelo espectador de hoje como autênticas na representação de uma natureza que não seria possível enxergar sem esses instrumentos (Scott, 20 I0: 31 ). Muito do formato da série surgiu dessa relação entre o objeto e o modo como conseguimos fazer imagens desse objeto. Não é possível fazer imagens de animais silvestres, que normalmente fogem ou mantêm uma distância de segurança dos seres humanos, sem a utilização de uma teleobjetiva. Este equipamento acaba sendo determinante, porque sem ele não temos como produzir a 
Parques do Brasil: a concepção de uma série de documentários de história natural e a promoção da conservação da biodiversidade e das unidades de conservação brasileiras

imagem e construir a narrativa.

Além das imagens, o som tem uma importância fundamental nessa construção. Nós concebemos a utilização de quatro elementos sonoros: a narração em OFF, o som ambiente, o som ambiente reconstruído ou interpretado e a trilha musical.

Para o nosso objetivo, o narrador é antes de tudo um contador de histórias. Uma voz impregnada do frescor de uma emoção genuína, de alguém que está vivendo uma experiência única, sentindo-se como numa grande aventura em um lugar que ele não conhecia antes, encontrando espécies que ele nunca viu. Para ele e para o espectador tudo deve parecer novo e surpreendente. É fundamental para esta narrativa que ambos vivenciem juntos a expedição. Fora o momento introdutório, o narrador não revela o que vai acontecer. E nunca se coloca numa posição de completo domínio do que está acontecendo.A proposta é que a narração transmita uma emoção de descoberta genuína.

O som ambiente cria uma atmosfera e dá à imagem tridimensionalidade. Este som nos diz: estamos naquele lugar. Ele nos transporta para a locação - o lugar do acontecimento -, e nos integra à imagem, porque ouvimos para além do que vemos. Ouvimos o que está fora do quadro, o que está escondido, atrás da gente, longe ou perto. Essa sensação somente o ambiente pode proporcionar. Através dele podemos destacar detalhes sutis, movimentos e ações de personagens: o bater de asas de um pássaro, o andar de um bicho na grama seca, entre outros.

Na pós-produção da série, podemos definir três tipos de som ambiente utilizados. $O$ primeiro é aquele que cria a atmosfera e traz um conjunto de elementos genéricos. Este é como uma base sonora, cobrindo boa parte do episódio. Nele temos o vento ou a ausência dele, o barulho da água, uma trovoada e vários sons de animais e veículos. Este som pode ser captado no ambiente original ou pode ser reconstruído a partir de um banco de áudio. Outro tipo é a vocalização de um animal específico. Normalmente, este som é captado junto com a imagem, mas também pode ser recriado, utilizando sons de outras imagens ou mesmo de um acervo. $O$ terceiro tipo é um som ambiente interpretado, que tem como objetivo criar uma ênfase narrativa ou uma licença poética e é elaborado em conjunto com a trilha sonora. Através deste som ilustramos, revelamos ou destacamos determinadas ações ou acontecimentos.

Como a narrativa é construída através de pequenas histórias que se sucedem numa linha cronológica, este último tipo de som ambiente junto com a trilha musical têm a função de destacar as histórias e dar ritmo à narrativa. A trilha musical é concebida com este desenho sonoro e leva em conta todos outros elementos existentes. Incorpora influências tanto de documentários da BBC quanto de filmes ficcionais, na linha de compositores como Hans Zimmer, George Fenton e John Williams.

A trilha tem uma base clássica e universal, agregando elementos da música contemporânea. $O$ objetivo é que esta crie uma ligação rápida com o imaginário musical fílmico do espectador. Para cada episódio, há uma trilha específica.Além dessa base universal, cada documentário apresenta nuances regionais identificando cada lugar/localidade a partir de um universo musical específico. Desta maneira, agrega outras referências musicais àquelas já citadas. E, por exemplo, no meio de uma base melódica calcada em instrumentos de cordas poderá surgir o som de uma sanfona ou de uma zabumba. Em outro trecho, entra uma guitarra. Mas isso sem perder o caráter universal, melódico e harmônico. A trilha precisa emocionar e conduzir o espectador na aventura do conhecimento de cada 
episódio.

Cada UC possui um tema musical específico e os personagens têm subtemas particulares, ressaltado características ou acontecimentos, intercalando momentos e significados diversos, definindo o tom de cada sequência. Através da trilha destacamos a diversidade de espécies e de ambientes, revelamos conflitos e os diferentes mundos que convivem no espaço de uma unidade de conservação, mostrando a beleza, a singularidade e a importância de cada animal, planta ou paisagem.

O documentário como instrumento de conservação

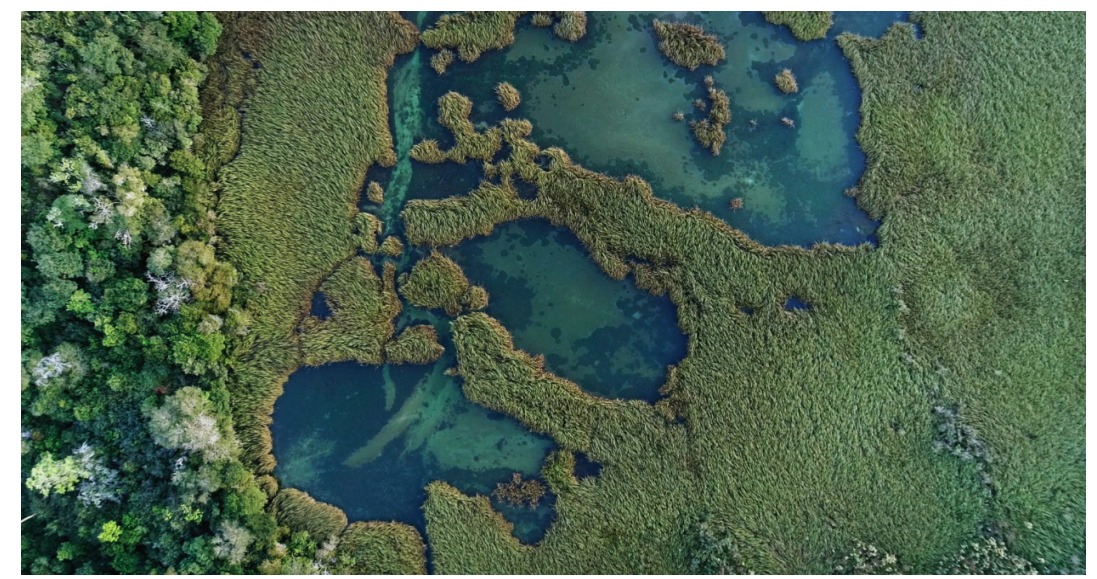

Imagem aérea/drone. Banhado do rio Perdido. Episódio Parque Nacional da Serra da Bodoquena, MS.

A pesquisa científica é um elemento fundamental para a realização de filmes de história natural. Segundo o ICMBio (2018), o número de pesquisas cresceu $29,34 \%$ entre 2014 e 2016 , mas a maior parte desse conhecimento continua restrita aos centros de pesquisa e às universidades. Para haver maior mobilização da sociedade em torno da conservação, inclusive dos Patrimônios Naturais, esse conhecimento precisa ser partilhado com diferentes atores sociais e o audiovisual surge como um instrumento privilegiado para fomentar essas relações e as trocas de conhecimento (Alvarenga e Sanches, 2018).

A discussão sobre as potencialidades do audiovisual enquanto instrumento de promoção da conservação da natureza surgiu no final da década de 80 e continua a gerar novos estudos (Davies, 1998; Louson, 2018). Nessas análises, apesar das diferentes visões, os resultados demonstraram que os filmes de história natural podem contribuir significativamente para ações de conservação da biodiversidade. No Brasil ainda não possuimos investigações nesse sentido, mas através dos relatórios diários de medição de audiência realizados pelo Kantar IBOPE onde a série Parques do Brasil aparece como um dos destaques da programação da TV Brasil, já é possível verificar que produções deste gênero têm grande aceitação popular, revelando o interesse das pessoas em conhecer a biodiversidade e as unidades de conservação brasileiras. Outros entendimentos sobre as potencialidades de uma produção como esta poderão surgir de processos participativos realizados em comunidades no entorno das unidades de conservação apresentadas.

Daí o esforço em produzir uma série que crie empatia com diferentes públicos, sem deixar de lado o conhecimento científico e questões referentes 
Parques do Brasil:a concepção de uma série de documentários de história natural e a promoção da conservação da biodiversidade e das unidades de conservação brasileiras

à conservação, incluindo os conflitos existentes. A ideia de agregar elementos pitorescos como ilustrações é a de trazer para dentro da narrativa um pouco do universo do filme e do romance de aventura, com todos aqueles elementos que encantam jovens e adultos. Nessa construção não se pretende criar paraísos naturais míticos, nem estabelecer relações calcadas pelo uso humano dos recursos naturais. $A$ influência antrópica é inequívoca e ela está presente em toda a narrativa, explicitada no impacto das atividades humanas nessas unidades e nos ambientes.

Em meados do século XIX, o naturalista Alexander von Humboldt buscou elaborar uma metodologia de construção do discurso descritivo científico com elementos estéticos que evidenciassem a subjetividade e a emoção do observador (Aliata, 2008: I24), integrando de maneira harmônica a cognição intelectual e a poética (Ricotta, 2003: 2I-23). Dessa forma, podemos imaginar que Humboldt estava ali gerando os conceitos para uma série de documentários de história natural contemporânea, que pudesse ao mesmo tempo: elaborar conhecimentos sobre a biodiversidade, promover a conservação de ambientes e espécies, e, de cativar e de mobilizar o espectador.

Referências

ADORNO,T.W. The idea of natural history. Stanford:Telos Press Plubishing, 1984 ALIATA, F. e SILVESTRI, G. A Paisagem como cifra de harmonia: relações entre cultura e natureza através do olhar paisagístico. Curitiba: Editora UFPR, 2008.

ALVARENGA, L. e SANCHES, C. Produção de TV e web busca popularizar o conhecimento sobre a biodiversidade. In QUIRINO, C. (org.) Boas práticas na gestão de unidades de conservação. Brasília: ICMBio, 2018.

ART \& HUMANITIES RESEARCH COUNCIL. Turning the Lens of the BBC's Natural History Unit. Disponível em: <https://ahrc.ukri.org/newsevents/news/ turning-the-lens-of-the-bbc-s-natural-history-unit/> Acesso em: 25 de Novembro de 2018.

ATTENBOROUGH, D. Naturaleza asombrosa en el arte: el arte en la historia natural de la era del descubrimiento. Tradução: Seven Servicios integrales. Madrid: Edimat Libros, 2017.

AUSTIN, T. Watching the world: screen documentary and audiences. New York: Manchester University Press, 2007.

BBC. Natural History on the BBC. Disponível em: <http://www.bbc.co.uk/pressoffice/pressreleases/stories/20II/07_july/08/nhu.shtml > Acesso em: 25 de Novembro de 2018.

BERALDO, T. do V. S. e SIMÕES, H.B. Contribuição do turismo em unidades de conservação federais para a economia brasileira: efeitos dos gastos dos visitantes em 20 I 7. Brasília: ICMBio, 2018.

BLUM,A. Picturing Nature: American Nineteenth-Century Zoological Illustration. Chichester: Princetown University Press, 1993.

BOUSÉ, D. Wildlife films. Philadelphia: University of Pennsylvannia Press, 2000.

BURNS, R.W. Television: an international history of the formative years. Londres: IET, I998.

CHRIS, C. Watching Wildlife. Minneapolis MN: University of Minnesota Press, 2006.

COUSINS, M. História do Cinema.Tradução Cecília Camargo Bartalotti. São Paulo: Martins Fontes, 2013. 
DA-RIN, S. Espelho partido: tradição e transformação do documentário. Rio de Janeiro:Azougue Editorial, 2004.

DAVIES, G. Networks of nature: stories of natural history film-making from the BBC. Londres: University College London, 1998.

FRANCO, J. L. de A. e DRUMMOND,J. A. Proteção à natureza e identidade nacional no Brasil, anos 1920-1940. Rio de Janeiro: Editora Fiocruz, 2009.

GOUYON, J.You Can't Make a Film about Mice just by Going out into a Meadow and Looking at Mice: Staging as Knowledge Production in Natural History Film-Making. In Staging Science: Scientific Performances on Street, Stage, and Screen. London UK : Palgrave Macmillan, 2016.

HAUSER,A. História social da arte e da literatura. São Paulo: Martins Fontes, 2003. ICMBio. Estatísticas - Cadastro e solicitação. Disponível em: http://www.icmbio. gov.br/sisbio/estatisticas.html Acesso em: nov. 2018.

IVAKHIV, A. J. Ecologies of the Moving Image: Cinema, Affect, Nature. Waterloo ON:Wilfred Laurier University Press, 2013.

JANSON, H.W. História geral da arte: $O$ mundo moderno. São Paulo: Martins Fontes, 2007.

LOUSON, E. Taking spectacle seriously: wildlife film and the legacy of natural history display. Science in Context. Cambridge UK: Cambridge University Press, 2018.

MABEY, R. Nature Cure. London UK: Chatto \& Windus, 2005.

MACDONALD, S. Up close and political: three short ruminations on ideology in the nature film. Film Quarterly, 2006.

METZ, C. A significação no cinema. São Paulo: Perspectiva 2004.

MILLS, B. The animals went in two by two: heteronormativity in television wildife documentaries. European Journal of Cultural Studies. Newbury Park: Sage Publishing, vol. I6, fascículo I, p. I00-I |4, 2013.

MITMAN, G. Reel Nature:America's romance with wildlife on film. Seattle: University of Washington Press, 2009.

NICHOLS, B. Introduction to documentary. Bloomington: Indiana University Press, 2001 .

OWENS, S. Gran diligencia, gracia y espíritu. In: Naturaleza asombrosa en el arte: el arte en la historia natural de la era del descubrimiento. Tradução: Seven Servicios integrales. Madrid: Edimat Libros, 2017.

PALMER, C. Shooting in the wild: an insider's account of making movies in the animal kingdom. San Francisco: Sierra Club Books, 2010.

RAMOS, F. P. Mas afinal...O que é mesmo documentário? São Paulo: Editora Senac São Paulo, 2008.

RICE,T. Voyages of discovery: three centuries of natural history exploration. New York: Clarkson N. Potter, 1999.

RICOTTA, L. Natureza, ciência e estética em Alexander von Humboldt. Rio de Janeiro: MAUAD, 2003.

SANDRONI, P. (org.). Novíssimo dicionário de economia. São Paulo: Editora Best Seller, 1999.

SCOTT, K. D. Popularizing science and nature programming: the role of 'spectacle' in contemporary wildlife documentary. Journal of Popular Film and Television, vol. 3 I, fascículo I, p. 29-35, 2010.

SCREENONLINE. Cuckoo's Secret, The (1922). Disponível em: < http://www. screenonline.org.uk/film/id//354742/index.html > Acesso em: 25 de Novembro de 2018.

SINGH, P. Narrative in wildlife films: how it shapes our understanding of the na- 
Parques do Brasil:a concepção de uma série de documentários de história natural e a promoção da conservação da biodiversidade e das unidades de conservação brasileiras

tural world and influences conservation choices. Montana: Montana State University, 2005.

STAFFORD, B. Good looking: essays on the virtue of images. Cambridge: MIT Press, 1996.

TV BRASIL. Expedições. Disponível em: <http://tvbrasil.ebc.com.br/expedicoes> Acesso em: 25 de Novembro de 2018a.

TV BRASIL. Parques do Brasil. Disponível em: <http://tvbrasil.ebc.com.br/parques-do-brasil/20 I8/05/conheca-serie-parques-do-brasil> Acesso em: 25 de Novembro de $2018 \mathrm{~b}$.

TV CULTURA. Repórter Eco. Disponível em: <http://tvcultura.com.br/programas/reportereco/> Acesso em: 25 de Novembro de 2018.

UNESCO. Patrimônio Natural no Brasil. Disponível em: <http://www.unesco.org/ new/pt/brasilia/natural-sciences/environment/natural-heritage/> Acesso em: 25 de Novembro de 2018.

WILLIAMS, R. Ideas of Nature. In: Problems in Materialism and Culture London: Verso, 1980.

WILD FILMHISTORY. Secrets of Nature:The Cuckoo's Secret (1922). Disponível em: <http://www.wildfilmhistory.org/film/296/The+Cuckoo\%27s+Secret.html> Acesso em: 25 de Novembro de 2018.

WULF,A. A invenção da natureza: a vida e as descobertas de Alexander von Humboldt. Tradução Renato Marques. Edição, I ${ }^{a}$. São Paulo: Planeta, 2016. 